\title{
REGIONAL CLIMATE CHANGES IN NORTH-EASTERN POLAND AND THEIR IMPACT ON MAIZE CROPS
}

\author{
Leszek Kuchar ${ }^{1}$, Zbigniew Szwejkowski², Bogumił Rychcik², Ewa Dragańska², \\ Iwona Cymes² \\ ${ }^{1}$ Department of Mathematics, Wroclaw University of Environmental and Life Sciences, ul. Grunwaldzka 53, 50-357 Wroclaw \\ ${ }^{2}$ Department of Water Resources, Climatology and Environmental Management, University of Warmia and Mazury in Olsztyn, \\ pl. Lodzki 2, 10-719 Olsztyn
}

\begin{abstract}
Aim of the study

Indication of changes in maize yield for grain and silage in connection with the observed climate changes.

\section{Material and methods}

Data from field experiments of the experimental station of the University of Warmia and Mazury since 1972 as well as meteorological data (air temperatures and precipitation). Calculations using the trend analysis of original variables and determined indexes (GDD, SPI, Sielianinov index), weather-yield linear models and elements of spectral analysis.
\end{abstract}

\section{Results and conclusions}

Changes in thermal conditions were demonstrated based on average air temperatures and the GDD index. There were no significant changes in atmospheric precipitation, showing a small periodicity of ten years, and no changes in monthly frequency with a deficit of precipitation (SPI analysis). It was demonstrated that changes in thermal conditions as well as the introduction of new maize varieties over fifty years significantly improved plant maturation, which resulted in a significant increase in grain weight. However, this did not affect the yield of maize for silage, neither in crop rotation nor in the monoculture system.

Keywords: climate change, maize, north-eastern Poland

\section{INTRODUCTION}

Maize originates from Latin America, hence it is a crop that requires appropriate technologies and a selection of suitable varieties to be grown in the soil and climate conditions prevalent in Poland, especially in its north-eastern part. Early efforts to improve maize cultivation productivity and to enlarge the total area of maize fields in Poland were made in the 1970s, and despite various obstacles they continue until today, mostly because of the unquestionable worth of maize as a source of energy, animal feed, and foodstuffs. In the foreseeable future, maize is likely to become make a larger contribution in the crop structure of Poland owing to the impact of global warming, which can stimulate the plant to produce higher yields and better yield quality, as expected by farmers. Globally, rising temperatures on the Earth are an undesirable phenomenon (IPCC, 2014), but as this process cannot be halted now and it would be counted as a success if the global temperature does not increase by more than $2^{\circ} \mathrm{C}$, the observed growth in temperature may be seen

凶e-mail: Leszek.Kuchar@upwr.edu.pl 
as a source of opportunities, for example in Polish agriculture, although it will probably entail new risks as well. Important measures that will allow us to avoid the problems, including possible losses in the productivity of farming, are an early recognition of local directions of changes and adaptation of technologies, i.e. fertilization regimes, suitable cultivars, adequate dates for plant cultivation treatments, etc. (Butler and Huybers, 2013).

The impact of weather conditions on the yield of maize is a well-known issue, particularly in the context of air temperature and atmospheric precipitation (Dudek and Żarski, 2009; Kovacevic et al., 2007; Szulc and Kruczek, 2008; Riha et al., 1996; Waha et al., 2013). The difficulty lies in the fact that high yields are achievable only at adequate proportions between temperature and rainfall, and therefore any prediction about the impact of global warming in Poland and elsewhere in the world on maize yields is burdened by much uncertainty (Eckersten et al., 2012; Lobell and Burke, 2008). The literature contains numerous descriptions of the response of maize to weather conditions regarding the growth rate and the volume and quality of yields (Barber et al., 1988; Lobell at al., 2013; Reidsma et al., 2009; Sulewska and Koziara, 2005; Szulce and Kruczek, 2008; Riha et al., 1996; Waha et al., 2013). Maize shows a very species-specific response to the weather factors, which - in addition to highly diverse combinations of meteorological factors and great spatial diversity of accompanying conditions - necessitates conducting numerous local experiments in order to build the foundation for the adaptation of maize cultivation to the current and future climatic conditions. Such was the aim of the study reported below, which relies on a field experiment, started in the past and providing data for our current analysis of the response of maize to weather conditions in north-eastern Poland.

\section{MATERIAL AND METHOD}

The field experiment was started in 1967, and maize was first sown in spring 1968. The experiment was located at a research station of the then Higher School of Agriculture in Olsztyn (today's University of Warmia and Mazury in Olsztyn), in north-eastern Poland. Until 1972, the crops were grown in monocultures. After- wards, fields cropped with monoculture plantations were divided into halves, and two types of cultivation were compared between 1972 and 1992: monoculture and crop rotation systems. The experiment has continued until the present day and will be continued in the future. For the purpose of this study, data from 1968-2016, i.e. covering nearly fifty years, were analysed. The experiment was established on sandy clay loam underlain by heavy loamy sand. The crop rotation system consisted of maize grown after sugar beet in a 6-year crop rotation, with the following crops (in order): spring barley, sowing pea, winter oilseed rape, winter wheat. The standard cultivation practice, in line with the current level of development of Polish agriculture, was implemented (fertilization, plant protection), in addition to which manure fertilization was applied once in each rotation cycle (at a dose of $30 \mathrm{t} \cdot \mathrm{ha}^{-1}$ ). During the entire experiment, the crop cultivars were replaced with newer ones, making every effort to maintain their earliness identified by a FAO number between 180 and 280 . The value of the FAO number weighted average for the two cultivars which once appeared simultaneously in the experiment was approximately 220 . The experiment was monitored in terms of the dynamics of plant development (development stages: sowing - emergence, emergence - flowering, flowering - dough stage), weed infestation, presence of plant pests, changes in the chemical properties of the soil). In the final stage of cultivation, the green (for ensiling) and dry matter yielding efficiency of crops was determined. Due to differences in the degree of ripeness over the years, our analysis did not take into account the data corresponding to the efficiency of grain production, or grain quality parameters, which were identified in some of the years.

The experiment was performed under the constant monitoring of meteorological conditions, especially temperature and precipitation. In order to solve the principal problem posed in this study, statistical analyses were carried out on the data obtained from the above field trial, which revealed time-related trends in crop yields. The relationship between yielding and temperature and rainfall total, as well as simple and aggregated indicators (Selyaninov's Index, Standardized Precipitation Index), on plant development dynamics and productivity were determined. The 
dependent variables were the yields of green mass and dry matter, as well as the yields of green mass, which are residual values after subtracting the values resulting from the trend equations (variance over the trend). Standard Precipitation index was calculated on the base sums of monthly precipitation transformed in function $f(P)=\sqrt[3]{P}$ and standarised using the formula below:

$$
S P I=\frac{f(P)-\mu}{\delta}
$$

where:

$\mu-$ average value of normalized series of precipitation;

$\delta$ - average standard deviation of standardized rainfall series.

Selyaninov's index was calculated using the formula:

$$
k=\frac{P \cdot 10}{\sum t}
$$

where:

P - monthly precipitation total

Analysing the connection between parameters listed above, we applied multiple correlation by the stepwise and dorsal methods. The periodicity of the phenomena was analysed using the Fourier spectral method. All statistics, simple and complex, were calculated using the STATISTICA software.

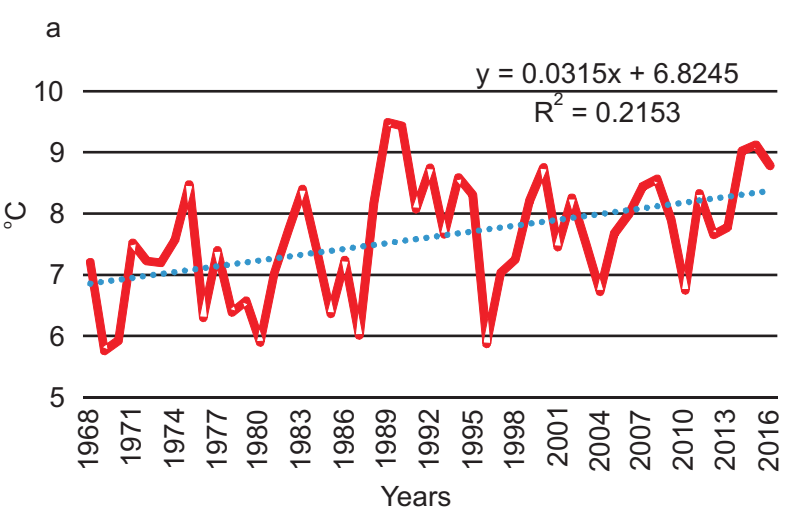

\section{RESEARCH RESULTS}

The weather conditions observed during the cultivation of maize in the experiment reported herein changed significantly over the whole period of the experiment. Above all, an increase in the mean annual temperature was noted. This increase was associated with a significant linear, time-specific tendency, expressed by the $\mathrm{R}^{2}$ value equal to 0.215 (see: Fig. 1), at an increase of about $0.003^{\circ} \mathrm{C} /$ year. Obviously, this tendency revealed certain oscillations, which were estimated by the Fourier spectrum analysis. The results of this analysis point to high values of the periodogram for an 8-year period. Having distinguished formal, ten-year-long periods, we calculated mean temperatures for each of these intervals. These results are set in Table 1. More information can be found in the report by Szwejkowski et al (2017).

Table 1. Decade averages of annual temperatures and annual precipitation totals

\begin{tabular}{ccc}
\hline Decades & $\begin{array}{c}\text { Temperatures } \\
{ }^{\circ} \mathrm{C}\end{array}$ & $\begin{array}{c}\text { precipitation } \\
(\mathrm{mm})\end{array}$ \\
\hline $1968-1977$ & 7.1 & 605.3 \\
\hline $1978-1987$ & 6.9 & 579.3 \\
\hline $1988-1997$ & 8.1 & 588.4 \\
\hline $1998-2007$ & 7.8 & 638.3 \\
\hline $2008-2016$ & 8.2 & 575.9 \\
\hline
\end{tabular}

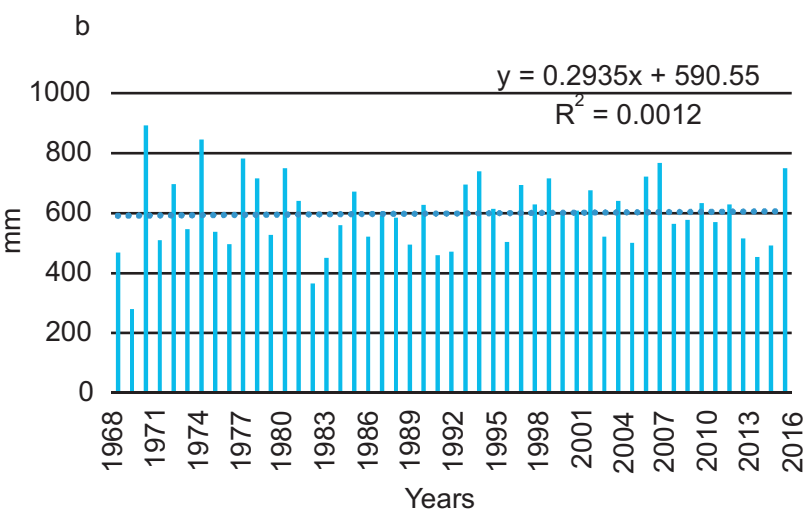

Fig. 1. Trend of average annual temperatures (a) and annual precipitation totals (b) in the years 1968-2016 
The figures implicate that an average temperature increased every other decade, and the greatest increase occurred between the second and the third decade of the studied period. The annual mean temperature from the years $2008-2016$ was higher by $1.1^{\circ} \mathrm{C}$ compared to that in the initial decade of 1968-1977, which meant it was higher than the average global temperature rise (IPCC, 2014). As for rainfall, its annual totals did not reveal any directional, statistically significant variation. The trend line is flat and the regression coefficient $R^{2}$ was merely 0.001 (see: Fig. 1).

The highest value of the Fourier spectrum analysis periodogram (see: Fig. 2) was obtained for the 24year oscillation, and for the oscillation between 3 and 4 years. Looking at precipitation diagrams, we note that more or less every four years, especially in the first, 24-year-long half of the research period, there were higher precipitation totals than the value determined by the trend line.

The most significant change in the course of the weather during the analysed period occurred with respect to values of some specialist parameters closely connected with the requirements of maize, mainly the Growing Degree Days indicator. This indicator is always taken into consideration when making estimates of the potential productivity of a given area for maize cultivation, especially in the USA, where most of maize varieties require Growing Degree Days between 2700 and 3100 to achieve the R6 stage, which is the full physical maturity (Abendrot et al., 2011; Kuchenbuch and Barber, 1988). Unfortunately, such high values are unattainable in north-eastern Poland, which is why maize is grown here for green matter to be ensiled in silos or for the so-called CCM (Corn Cob Mix), i.e. a fragmented mixture of maize cobs grown to the highest possible maturity stage. Values of the GDD calculated according to the recommended procedure (Abendrot et al., 2011) from sowing to the soft dough maturity stage (or to the date of harvest, if this stage has not been reached) oscillated from below 1200 , particularly in years with chilly weather during the growing season, i.e. 1978 and 1987, to $2200 \mathrm{~mm}$ in the year 2002. Thus, the change in air temperatures noted until now has been far from sufficient to ensure that maize cultivation in north-eastern Poland could attain the highest level of productivity. The data illustrated in Figure 3 show that there is a distinct and highly significant trend for increasing values of the GDD in the analysed period. The value of $\mathrm{R}^{2}$ was as much as 0.41 , and an annual increase in GDD amounted to 5.32. Thus, to achieve the minimal threshold value of GDD, as mentioned above, we would need another 50 years of temperature changes, should they proceed at the current rate. An analysis for central and western Poland, made previously, showed that such thermal conditions could be reached in that region much sooner (Dragańska et al., 2008).

Monthly values of the Standardized Precipitation Index SPI are presented graphically (see: Fig. 4). This index lends itself to an assessment of moisture conditions during the growing season of plants. Although the SPI does not indicate whether the rainfall values
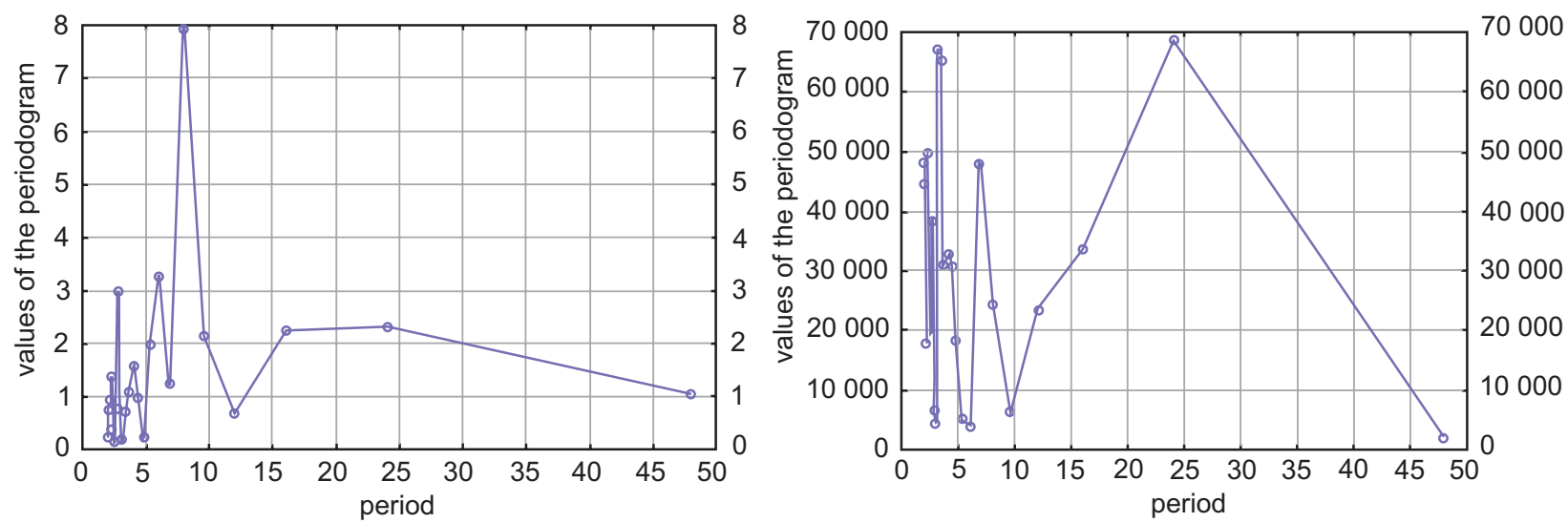

Fig. 2. The Fourier's spectral analysis. Periodicity of changes in the average annual temperature (a) and average annual precipitation totalsn 


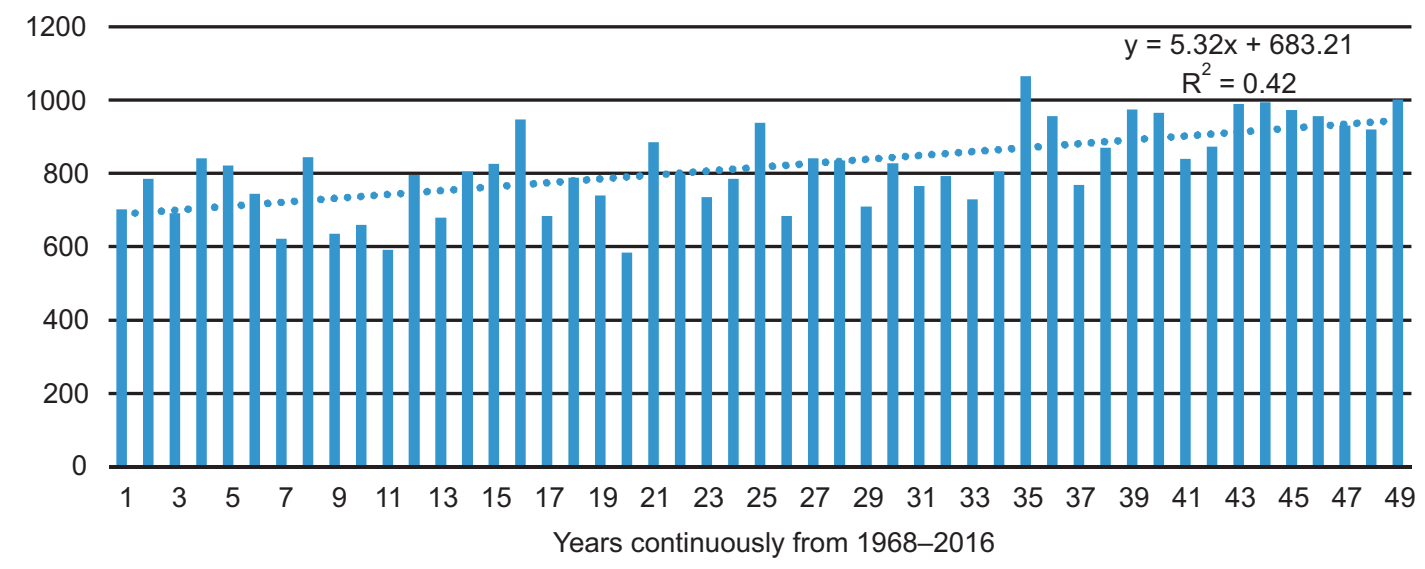

Fig. 3. Growing Degree Days (GDD) during growing seasons of maize in ${ }^{\circ} \mathrm{C}$ in fifty-years period (years 1968-2016)

are adequate to the requirements of specific plant species, including maize, it does inform us about changes in relationships between rainfall and average conditions noted in a given area (series of observations are transformed by the function $\left.\mathrm{f}(\mathrm{P})=(\mathrm{P})^{1 / 3}\right)$. The total sum of precipitation changed in the same way as the SPI values. Should we agree with the relevant references (Dudek and Żarski, 2009) suggesting that a generalised optimum precipitation value over the analysed area lies between -0.5 and 0.5 , we can conclude that the frequency of the occurrence of values above 1, i.e. a situation with relatively high rainfall values, was the lowest in April and the highest in August.

The SPI values of more than -1, implicating periods of moderate and heavier drought, appeared just as frequently, and corresponded to $15 \%$ of the time in most of the months. This means that the moisture conditions were within normal levels. The analysis of the situation with the SPI applied as a tool had a rather nominal significance, because it only pointed to the fact that the distribution of rainfall was random and corresponded to a normal distribution. This fact is also implicated by the trend analysis, which shows that standardized precipitation volumes do not present any tendency of change. The Selyaninov's hydrothermal index is much more suited to diagnosing the situation (see: Fig. 5). The hydrothermal index proposed by Selyaninov combines two values: temperature and rainfall, and can demonstrate quite precisely the availability of water to plants (in general, rather than in relation to particular plant species). The construction of this index means that the higher the value it achieves, the more marked the balance between amount of precipitation and its availability to plants. In general, values within the interval of 0 to 1 point to drought, while values above 1 implicate a positive balance of rainfall. The data obtained for our study indicate that the hydrothermal conditions in north-eastern Poland were deteriorating over the analysed multi-annual period. This is a justified conclusion, even though no statistically confirmed trend was noted in any of the months. In four out of the six months of the plant-growing season, such tendency was visible (insignificant due to the high variability of rainfall between years), but it was only in July that the trend was reversed. Near-drought conditions, defined according to the Selyaninov's index values, most often occurred in April, July and August, at a frequency of 25,27 and $29 \%$, respectively. The Selyaninov's index fell below 1 least frequently in the month of June (in $14 \%$ of the years).

Against the background of the climatic conditions, presented above, the dates of sowing the crops and their life cycle rhythm developed. Data are presented in Figure 6. The progressing climate warming made it possible to sow plants accordingly earlier. While at the beginning of the analysed period, in the late 1960s and early 1970s, the sowing dates fell in May, since the 1990s it has become possible to start sowing maize at the end of April and in the early days of May. The equation of the trend shows that the annual acceleration of sowing dates was 0.39 day. This means that during the 49 years submitted to our analysis, the 


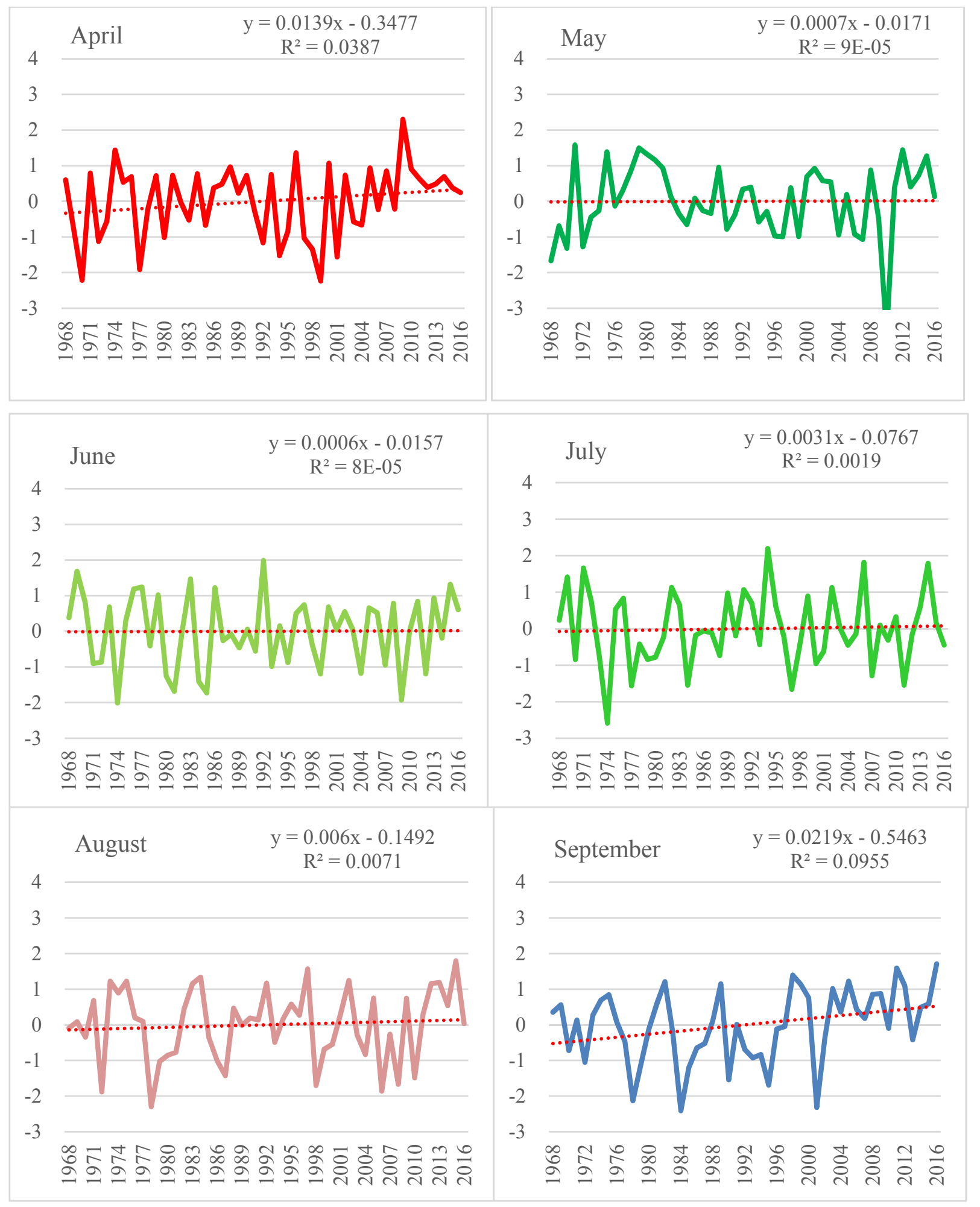

Fig. 4. Standardized Precipitation Index (SPI) during growing seasons of maize in the years 1968-2016 


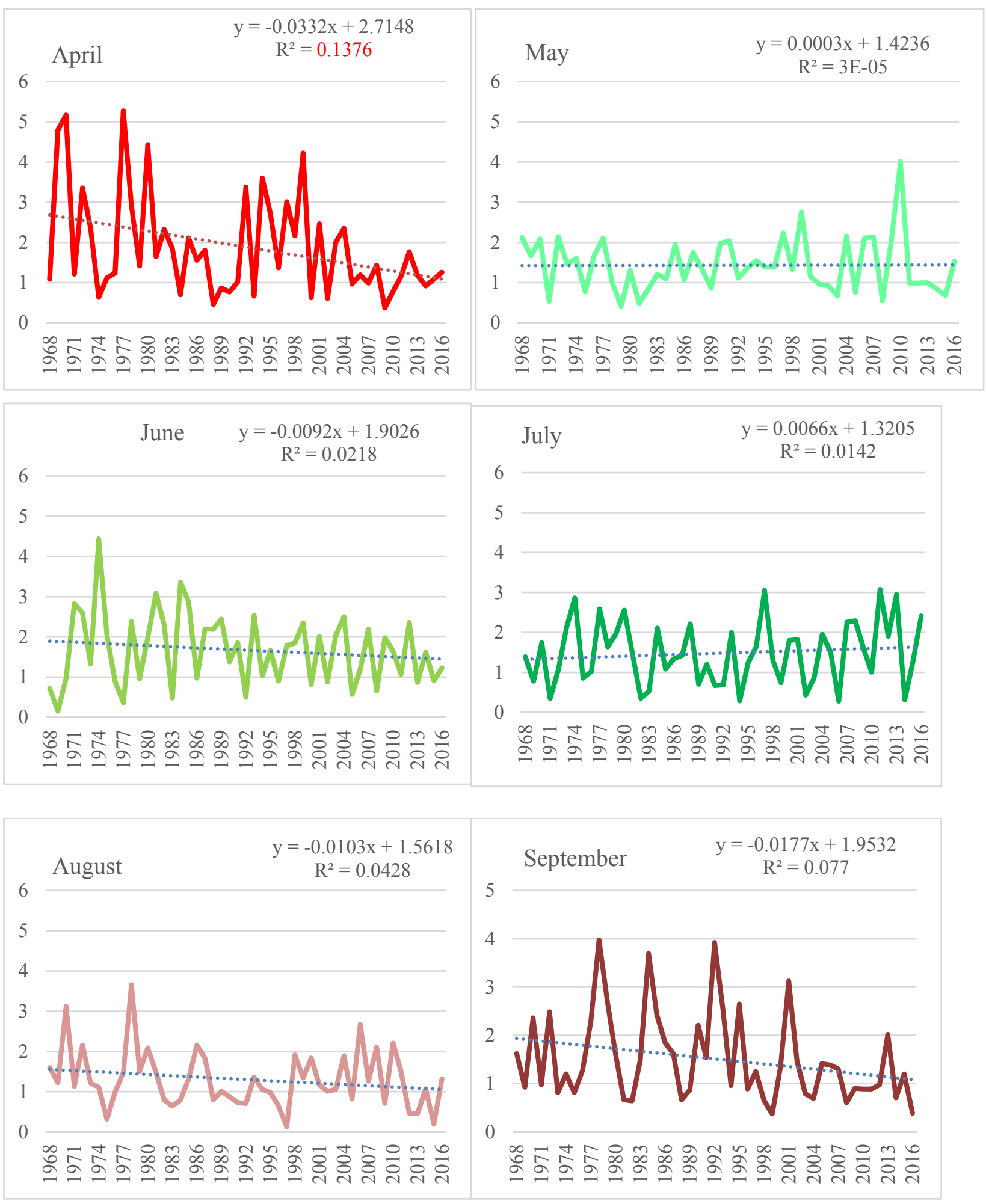

Fig. 5. Selyaninov's Index during maize growing seasons in the years 1968-2016 


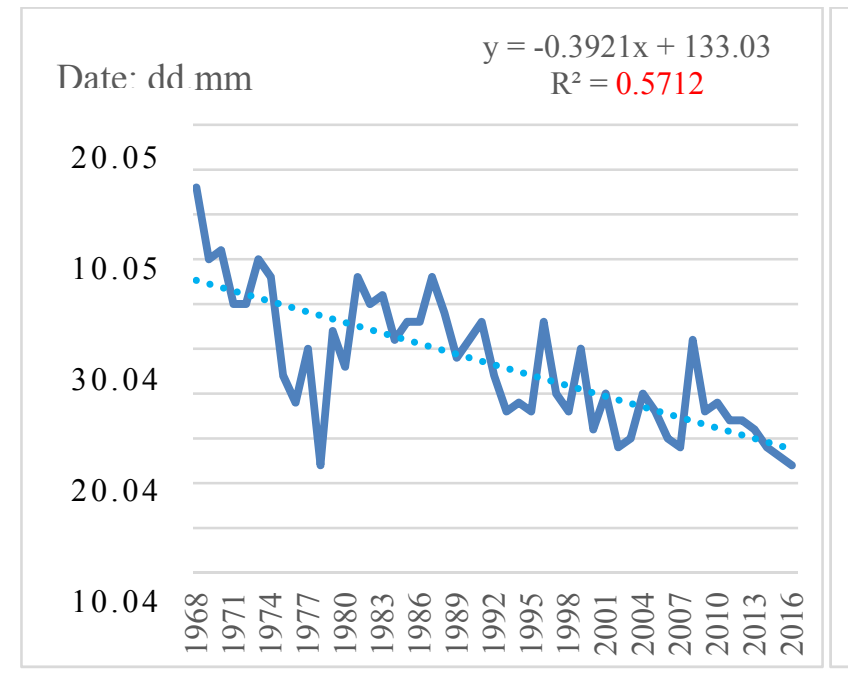

a

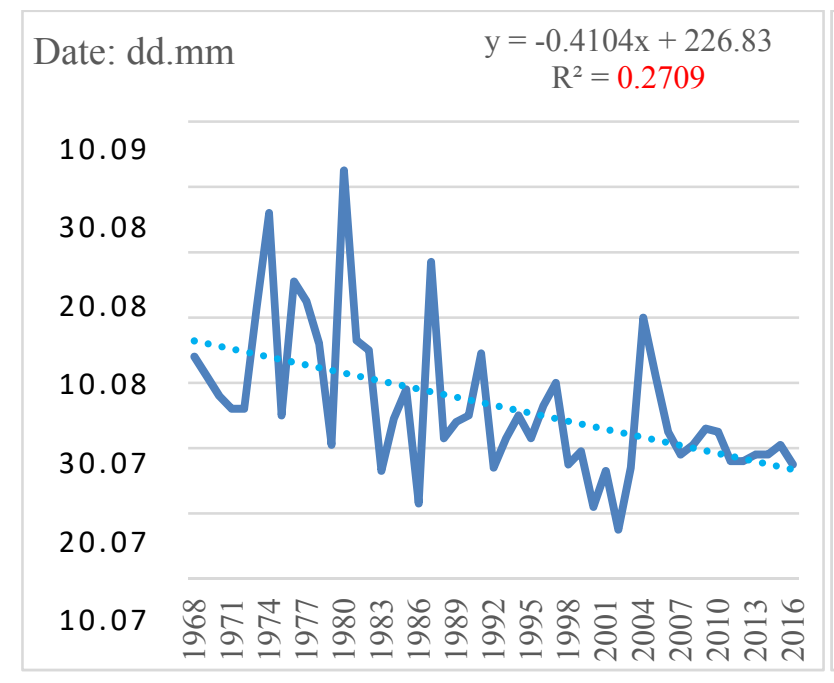

Date: dd.mm

$y=-0.448 x+149.8$

$\mathrm{R}^{2}=0.5451$

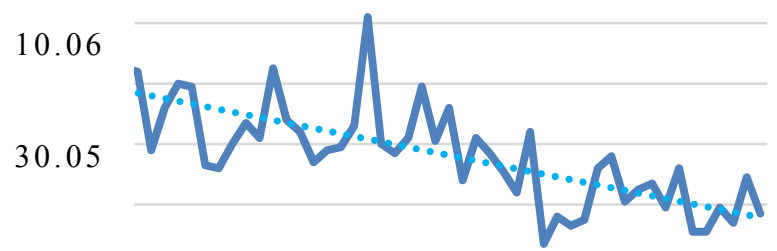

20.05

10.05

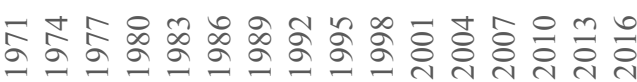

b

C

Date: dd.mm $\quad \begin{gathered}\mathrm{y}=-0.576 \mathrm{x}+265.37 \\ \mathrm{R}^{2}=0.2516\end{gathered}$

05.10

20.09

05.09

20.08

05.08

25.07

10.07

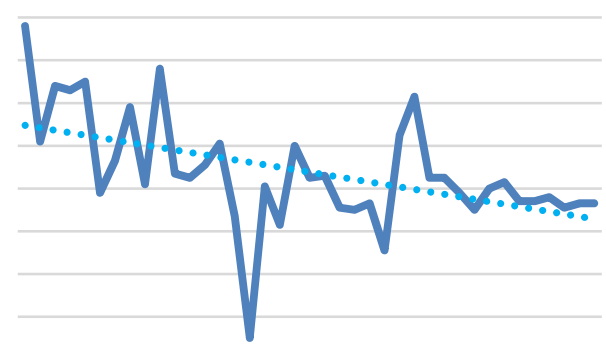

車

d

Fig. 6. Time trend of dates of plant growth development periods in the years 1968-2016 (a - sowing, b-emergence, c flowering, $d$ - maturity)

sowing date was pushed forward by 19 days. However, two years, 1975 and 1978, distinguish themselves against the tendency of the progressively earlier sowing dates over the period of 1968-2016. In these two years, plants were sown on the dates close to the ones that occurred at the end of this time period. We should add that a date of sowing was not always selected because of the objective agro-technical conditions, as there were a few years when the sowing of plants was postponed by 1 or 2 days due to organizational considerations.

At almost the same pace as the acceleration of sowing, the dates of plant emergence changed. The difference between the earliest and the latest plant emergence dates was 37 days (the difference between the years 1987 and 2000). In this case, we deal with 
the events that were dependent almost exclusively on climatic factors. The equation of the trend of changes in the onset of emergence showed statistical significance at the level of $\mathrm{R}^{2}=0.55$, while the pace at which the emergence time accelerated was 0.45 days per year. Following the earlier sowing and emergence, the plants reached the flowering and dough stages sooner. In the first case, the annual acceleration resulting from the trend equation was rounded to 0.4 , while in the latter one it averaged 0.6 day a year. The crops were always harvested after reaching the dough stage of ripeness, on a date that depended on the conditions found on the field and organizational matters, which is the reason why it is impossible to provide confirmation of the linear trend for the acceleration of harvest, and in this situation a power function would be best suited.

Evidence supporting the observation implicating the key importance of the date of sowing in the rhythm of the development of maize arises from the analyses of the duration of particular periods between the beginning dates of subsequent development stages (see: Fig. 7). Analyses of regressions performed in an attempt to determine correlation between the duration of particular development stages in days and the progressing time of the experiment did not verify significant correlation when tested in a linear format, ex-

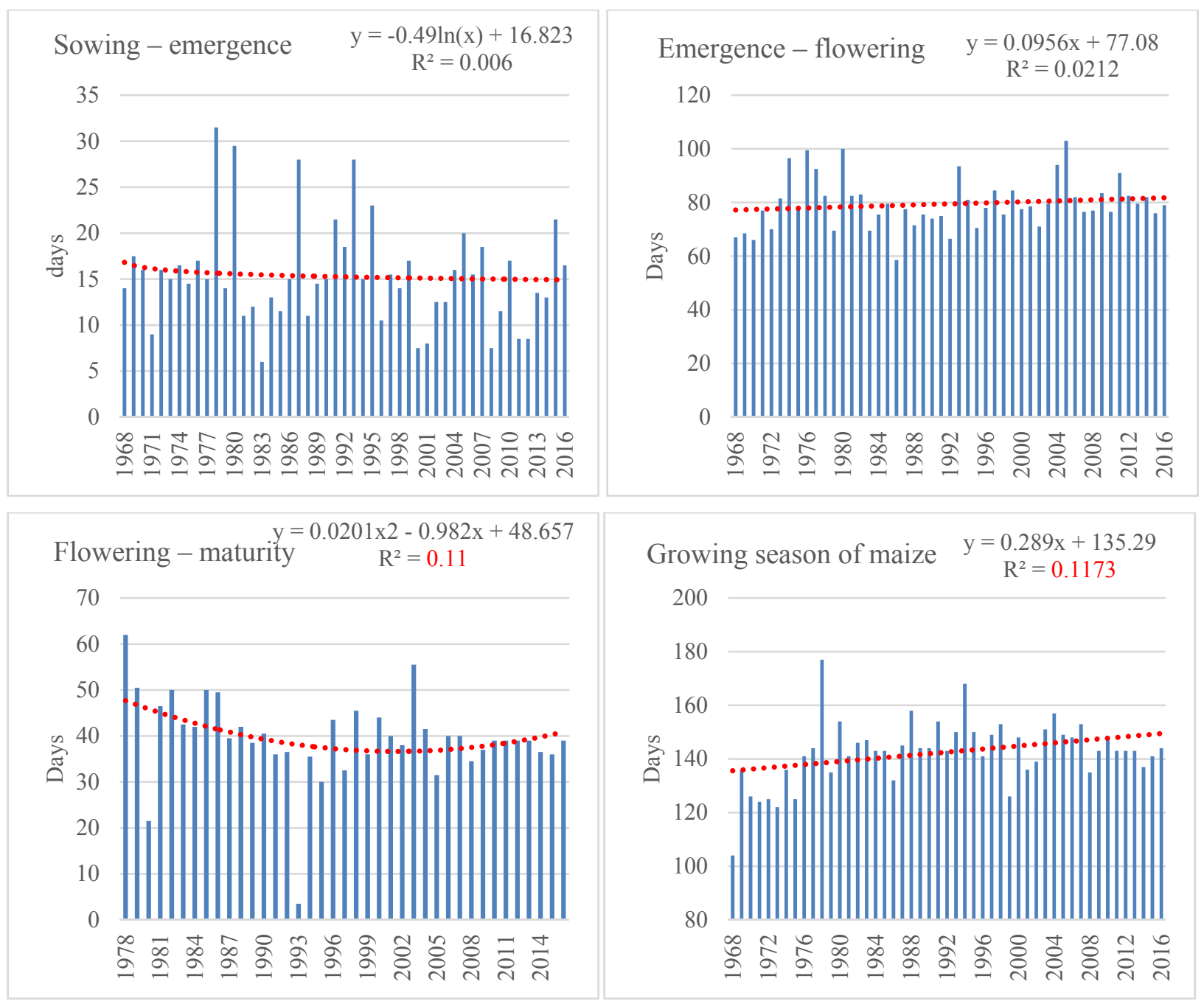

Fig. 7. Duration of development stages of maize in days in the years 1968-2016 
cept for the time interval between dough ripeness and harvest, which depended on time according to an exponential function (it lengthened this stage in the first phase of the experiment, and shortened it afterwards).

Maize grown in the conditions typical of north-eastern Poland proves to be a crop characterized by a very high variation of yielding. The extreme values of green matter yields were 22.5 and $75.1 \mathrm{t} \cdot \mathrm{ha}^{-1}$ when grown in a crop rotation system, and 22 and $62.5 \mathrm{t} \cdot \mathrm{ha}^{-1}$ in a monoculture. Maize cultivated in crop rotation produced yields of $53.6 \mathrm{t} \cdot \mathrm{ha}^{-1}$ on average, which was by $9.5 \mathrm{t} \cdot \mathrm{ha}^{-1}$ higher than in monoculture. The standard deviation calculated for the time period of nearly 50 years was $11.71 \mathrm{t} \cdot \mathrm{ha}^{-1}$ for crop rotations and slightly less, i.e. $9.23 \mathrm{t} \cdot \mathrm{ha}^{-1}$, for monocultures. In both cultivation systems, the value of the variability coefficient was 0.21 (see: Fig. 8).

Changes in the productivity of green matter of plants did not follow a linear trend. Values of $\mathrm{R}^{2}$ proved to be very low, above statistical significance threshold of 0.07 , and not significant statistically (see: Fig. 8). The Fournier spectrum analysis demonstrated the presence of certain oscillation, with the highest values of the periodogram found for periods of 3,4 and 6 years in the case of crop rotations, and 2.5 and 4 years for maize grown in a monoculture (see: Fig. 10). Obviously, some cognitive value, in this case, can be ascribed to the total numerical values of oscillation pe- riods, as the cycle of cultivation starts and ends in the same year.

The different stages of plant maturity achieved under varied weather conditions during the research period meant that dry matter yields, i.e. the mass determined after drying harvested yields to constant weight at $105^{\circ} \mathrm{C}$, served better as an indicator of plant yielding. The results are shown in Figure 9. With fluctuations from 5.5 to $26 \mathrm{t} \cdot \mathrm{ha}^{-1}$ (crop rotation) and $5.5-23$ $\mathrm{t} \cdot \mathrm{ha}^{-1}$ (monoculture), there was a significant tendency of increasing dry matter yields at a rate of $0.17 \mathrm{t} \cdot \mathrm{ha}^{-1}$ a year (crop rotation) and $0.09 \mathrm{t} \cdot \mathrm{ha}^{-1}$ a year (monoculture). These data prove that the weather conditions during the plant growing season, alongside the technological progress, contributed to a more efficient production of maize in north-eastern Poland during the analysed five decades. The dry matter yield depended on the sowing date and the date of emergence. The earlier the sowing date and the emergence date, the drier the matter collected. Meanwhile, the delay in the flowering phase led to a reduction in yield. The above statements are based on a regression analysis. The correlation between the date of sowing plants and the dry matter yield is expressed by the regression equation: $y=45.46-0.24 x$, with $p=0.003, R 2=0.21$. For the impact of the date of emergence on the dry matter yield, the equation was changed to: $y=33.01-0.12 x$, with $\mathrm{p}=0.002, \mathrm{R} 2=0.17$. Meanwhile, the increasing

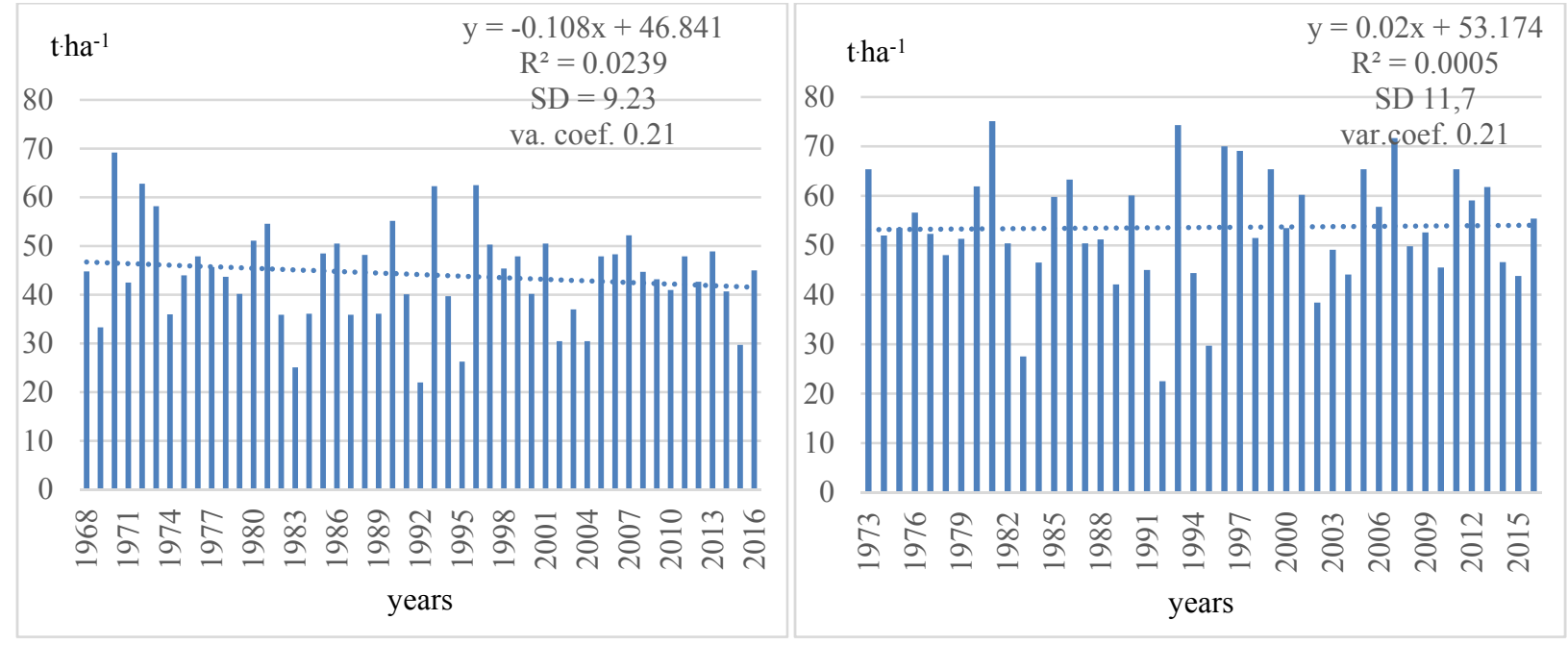

Fig. 8. Yields of green matter of maize (left - monoculture - average $\left.44.1 \mathrm{tha}^{-1}\right)$, (right - crop rotation - average 53.6 tha $\left.{ }^{-1}\right)$ in the years 1968-2016 


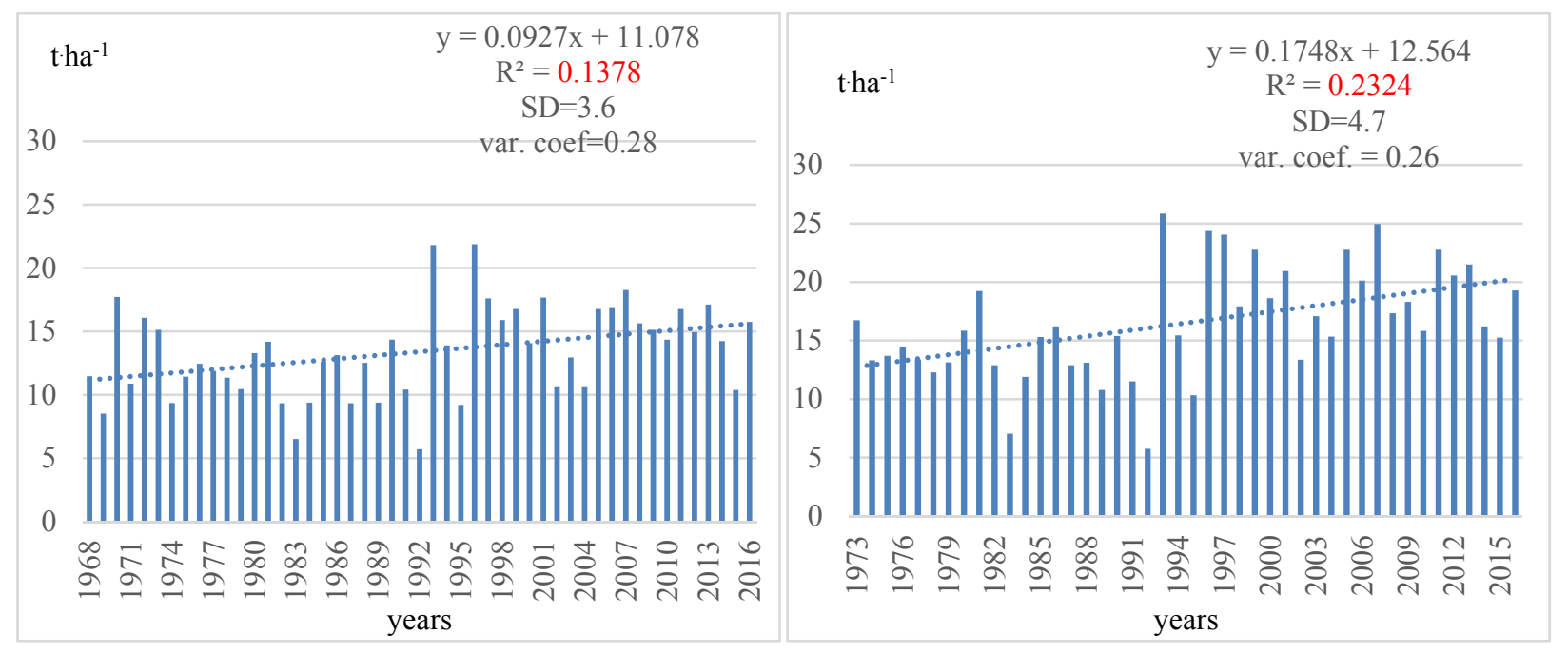

Fig. 9. Yields of dry matter of maize (left - monoculture - average $13.4 \mathrm{t} \cdot \mathrm{ha}^{-1}$ ), (right - crop rotation - average $16.5 \mathrm{t} \cdot \mathrm{ha}^{-1}$ ) in the years 1968-2016
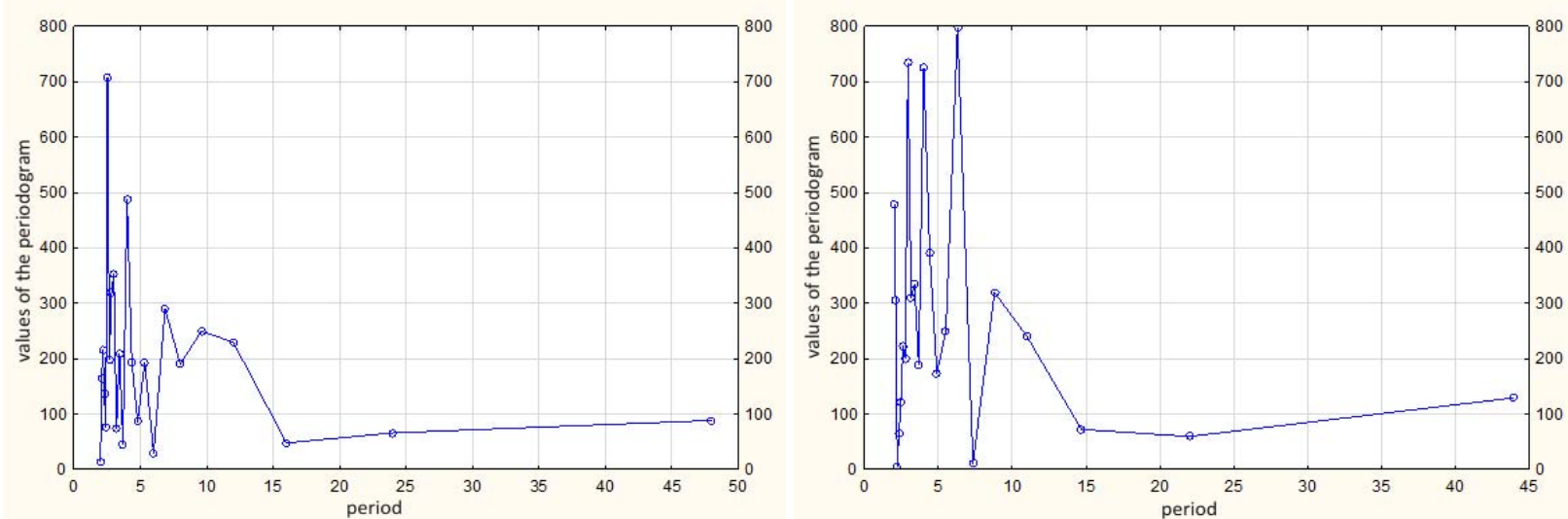

Fig. 10. The Fourier's spectral analysis. Periodicity of maize yield grown in monoculture (left) and in crop rotation system (right)

length of the period from emergence to flowering led to an increase in the yield according to the formula: $\mathrm{y}=3.96+0.16 \mathrm{x}$ (where $\mathrm{x}$ is the number of days from beginning of the year).

On the basis of multiple correlation analyses, an attempt was made to determine which of the tested weather parameters and to what extent had an impact on the yield of green and dry matter in maize grown in crop rotation and monoculture, and on the size of residual values, having taken into account the temporal trend of yield changes - variances over the trend (see: Table 2). The result of the experiment clearly confirms the effect of the average annual temperature on the green mass yield of plants grown in a crop rotation. The factor was not demonstrated to have a similar impact in the case of monoculture. However, the average annual and seasonal temperatures turned out to be significant in terms of the impact on the dry matter yield of monoculture cultivation and on the residual values in crop rotation and monoculture (in the last case, only 
Table 2. Plots of the correlations - parameters: temperatures/temperatures and precipitation - yield of green and dry matter of maize

\begin{tabular}{|c|c|}
\hline \multicolumn{2}{|l|}{ Yield of green matter in crop rotation } \\
\hline $\mathrm{y}=109.29-3.99_{\mathrm{ty}}$ & $\mathrm{p}=0.03, \mathrm{R}^{2}=0.10, \mathrm{SEE}=11.46$ \\
\hline $\mathrm{y}=78.64+0.13_{\mathrm{pm} 7}+0.06_{\mathrm{pm} 6}+0.08_{\mathrm{pm} 5}+0.93_{\mathrm{tm} 5}$ & $\mathrm{p}=0.0004, \mathrm{R}^{2}=0.46, \mathrm{SEE}=9.23$ \\
\hline \multicolumn{2}{|l|}{ Yield of dry matter in crop rotation } \\
\hline $\mathrm{y}=2.29+0.05_{\mathrm{pm} 7}+0.89_{\mathrm{tm} 4}+0.04_{\mathrm{pm} 5}+0.02_{\mathrm{pm} 6}$ & $\mathrm{p}=0.005, \mathrm{R}^{2}=0.39, \mathrm{SEE}=3.85$ \\
\hline \multicolumn{2}{|l|}{ Yield of dry matter in monoculture } \\
\hline $\mathrm{y}=0.93_{\mathrm{tm} 8}+0.63_{\mathrm{tm} 4}-0.28_{\mathrm{tm} 3}+0.31_{\mathrm{tm} 7}$ & $\mathrm{p}=0.002, \mathrm{R}^{2}=0.35, \mathrm{SEE}=3.04$ \\
\hline $\mathrm{y}=2.65+1.44_{\mathrm{ts}}$ & $\mathrm{p}=0.01, \mathrm{R}^{2}=0.15, \mathrm{SEE}=3.34$ \\
\hline$y=-15.29+2.06_{t y}$ & $\mathrm{p}=0.002, \mathrm{R}^{2}=0.28, \mathrm{SEE}=3.06$ \\
\hline $\mathrm{y}=0.73_{\mathrm{tm} 8}+0.70_{\mathrm{tm} 4}-0.26_{\mathrm{tm} 3}-0.03_{\mathrm{pm} 4}+0.44_{\mathrm{tm} 7}+0.01_{\mathrm{pm} 7}$ & $\mathrm{p}=0.04, \mathrm{R}^{2}=0.39, \mathrm{SEE}=3.00$ \\
\hline \multicolumn{2}{|c|}{ Variance over the trend - of yields of dry matter in crop rotation } \\
\hline $\mathrm{y}=20.18+1.16_{\mathrm{tm} 8}$ & $\mathrm{p}=0.003, \mathrm{R}^{2}=0.17, \mathrm{SEE}=3.69$ \\
\hline $\mathrm{y}=9.65+1.26_{\mathrm{ts}}$ & $\mathrm{p}=0.03, \mathrm{R}^{2}=0.09, \mathrm{SEE}=3.86$ \\
\hline $\mathrm{y}-20.25+1.44_{\mathrm{ty}}$ & $\mathrm{p}=0.02, \mathrm{R}^{2}=0.11, \mathrm{SEE}=3.82$ \\
\hline $\mathrm{y}=1.19+0.45_{\mathrm{tm} 6}$ & $\mathrm{p}=0.0008, \mathrm{R}^{2}=0.45, \mathrm{SEE}=3.15$ \\
\hline \multicolumn{2}{|c|}{ Variance over the trend - of yields of dry matter in monoculture } \\
\hline$y=15.54+1.11_{\text {ty }}$ & $\mathrm{p}=0.03, \mathrm{R}^{2}=0.10, \mathrm{SEE}=3.10$ \\
\hline
\end{tabular}

Abbreviations of independent variables: tm 4 ...tm 8 - average monthly temperatures from April to August, pm3 ...pm8 - monthly precipitation totals, ts - average temperatures of growing season, ty - average yearly temperatures

the average annual temperature). Significant regression equations were also obtained, considering the average monthly temperatures and the monthly precipitation totals, however, it is virtually impossible to explain why this or another factor influenced different measures of plant efficiency in individual cultivation variants.

Assuming as independent variables only the values of precipitation totals in the year, in the growing season and in individual months, the result was obtained, which indicates that these factors had a significant impact on the yield of maize cultivated in a crop rotation - one case was confirmed for monocultures (see: Table 3). In this case, the influence of annual and seasonal values was also apparent, while significant monthly sums mainly related to the months of the final growing phase. The use of rainfall aggregate indicators (SPI and Selyaninov's Index - see: Tables 4 and 5) did not clarify the interpretation of the impact of precipitation on the yield of plants in the discussed experiment, because the configurations of significant variables appearing in the equations were similar to those presenting the average monthly rainfall.

The analysis of maize cultivation discussed above, under the changing climatic conditions, justifies a claim that the prospects of growing this species in north-eastern Poland seem promising. Despite the lack of unequivocal evidence to support it, a major breakthrough can be expected in the near future, especially in the cultivation of maize for grain, particularly that the progress that has been achieved in research and practice over the past years is already impressive. The weather conditions, particularly the temperature, have contributed to the improved maize cultivation results, although new varieties (even within the same group of earliness) have played an important role as well. Gen- 
Kuchar, L., Szwejkowski, Z., Rychcik, B., Dragańska, E., Cymes, I. (2021). Regional climate changes in north-eastern Poland and their impact on maize crops. Acta Sci. Pol., Formatio Circumiectus, 20 (1), 3-18. DOI:

Table 3. Plots of the correlations - parameters: precipitation - yield of green and dry matter of maize

\begin{tabular}{|c|c|}
\hline \multicolumn{2}{|l|}{ Yield of green matter in crop rotation } \\
\hline $\mathrm{y}=31.76+0.13_{\mathrm{pm} 7}+0.70_{\mathrm{pm} 8}+0.08_{\mathrm{pm} 6}$ & $\mathrm{p}=0.0009, \mathrm{R}^{2}=0.39, \mathrm{SEE}=9.75$ \\
\hline $\mathrm{y}=32.21+0.06_{\mathrm{ps}}$ & $\mathrm{p}=0.007, \mathrm{R}^{2}=0.22, \mathrm{SEE}=10.67$ \\
\hline $\mathrm{y}=28.39+0.04_{\mathrm{py}}$ & $\mathrm{p}=0.002, \mathrm{R}^{2}=0.18, \mathrm{SEE}=10.92$ \\
\hline \multicolumn{2}{|l|}{ Yield of green matter in monoculture } \\
\hline $\mathrm{y}=49.45+0.01_{\mathrm{pm} 3}-0.12_{\mathrm{pm} 4}-0.01_{\mathrm{pm} 5}-0.01_{\mathrm{pm} 6}-0.02_{\mathrm{pm} 7}$ & $p=0.75, R^{2}=0.08, S E E=9.53$ \\
\hline \multicolumn{2}{|l|}{ Yield of dry matter in crop rotation } \\
\hline $\mathrm{y}=8.33+0.05_{\mathrm{pm} 7}+0.04_{\mathrm{pm} 5}+0.02_{\mathrm{pm} 6}$ & $\mathrm{p}=0.01, \mathrm{R}^{2}=0.25, \mathrm{SEE}=4.04$ \\
\hline $\mathrm{y}=9.02+0.02_{\mathrm{ps}}$ & $\mathrm{p}=0.01, \mathrm{R}^{2}=0.15, \mathrm{SEE}=4.35$ \\
\hline $\mathrm{y}=7.51+0.01_{\mathrm{py}}$ & $\mathrm{p}=0.01, \mathrm{R}^{2}=0.14, \mathrm{SEE}=4.37$ \\
\hline \multicolumn{2}{|c|}{ Variance over the trend - of yields of dry matter in crop rotation } \\
\hline $\mathrm{y}=7.76-0.03_{\mathrm{pm} 7}-0.02_{\mathrm{pm} 8}-0.02_{\mathrm{pm} 6}-0.02_{\mathrm{pm} 5}$ & $\mathrm{p}=0.01, \mathrm{R}^{2}=0.33, \mathrm{SEE}=3.42$ \\
\hline $\mathrm{Y}=7.04-0.02 \mathrm{ps}$ & $\mathrm{p}=0.004, \mathrm{R}^{2}=0.33, \mathrm{SEE}=3.75$ \\
\hline $\mathrm{Y}=8.19-0.01_{\mathrm{py}}$ & $\mathrm{p}=0.003, \mathrm{R} 2=0.17, \mathrm{SEE}=3.68$ \\
\hline
\end{tabular}

Abbreviations of independent variables: pm3...pm8 - monthly precipitation totals from March to August, ps - precipitation totals for growing season, py -annual precipitation totals

Table 4. Plots of the correlations - parameters: SPI (Standard Precipitation Index) - yield of green and dry matter of maize

\begin{tabular}{|c|c|}
\hline \multicolumn{2}{|l|}{ Yield of green matter in crop rotation } \\
\hline $\mathrm{y}=53.31+0.57_{\text {SPI_ }}-0.30_{\text {SPI }_{-}}-1.44_{\text {SPI_6 }}-4.73_{\text {SPI_ } 7}-2.22_{\text {SPI_ } 8}$ & $\mathrm{p}=0.03, \mathrm{R}^{2}=0.15, \mathrm{SEE}=11.04$ \\
\hline \multicolumn{2}{|l|}{ Yield of dry matter in crop rotation } \\
\hline $\mathrm{y}=16.13-1.32_{\text {SPI } 7}$ & $\mathrm{p}=0.03, \mathrm{R}^{2}=0.07, \mathrm{SEE}=4.49$ \\
\hline \multicolumn{2}{|c|}{ Variance over the trend - of yields of dry matter in crop rotation } \\
\hline $\mathrm{y}=-0.03+1.55_{\text {SPI_7 }}+0.75_{\text {SPI_8 }}$ & $\mathrm{p}=0.01, \mathrm{R}^{2}=0.15, \mathrm{SEE}=3.70$ \\
\hline
\end{tabular}

Abbreviations of independent variables: SPI_3...SPI_8, monthly values of SPI, from March to August

erally, the interpretation of the information provided in this paper is very difficult due to differences in weather conditions between years, typical for our climate zone, especially in terms of atmospheric precipitation volumes. Numerous experiments conducted in Poland and in other countries demonstrate clearly the importance of water availability to plants when air temperatures increase (Bocchiola et al., 2012, Dudek and Zarski, 2009; Elsgaard et al., 2012; Kovacevic e tal., 2007; Kuchar, 1989; Kuchenbuch et al., 2013). For successful cultivation of maize under the conditions of north-eastern Poland, it will be necessary to improve the regionally implemented technologies of growing this plant species, a problem which the field experiment, set up 50 years ago, did not take into account. Moreover, as demonstrated by other experiments, an increase in air temperatures does not induce an increase in the productivity of maize unless it is accompanied by a considerable rise in the minimal temperature (Liu et al., 2012). In general, the changes in the climate of the north-eastern part of Poland, both the on-going and predicted ones, may mean that yields of 
Table 5. Plots of the correlations: parameters: Selyaninov's Index - yield of green and dry matter of maize

\begin{tabular}{|l|l|}
\hline \multicolumn{2}{|l|}{ Yield of green matter in crop rotation } \\
\hline $\mathrm{y}=36.61+6.85_{\mathrm{k} 7}+2.20_{\mathrm{k} 6}+2.18_{\mathrm{k} 8}$ & $\mathrm{p}=0.003, \mathrm{R}^{2}=0.22, \mathrm{SEE}=10.56$ \\
\hline Yield of dry matter in crop rotation & $\mathrm{p}=0.008, \mathrm{R}^{2}=0.18, \mathrm{SEE}=4.24$ \\
\hline $\mathrm{y}=12.00+2.58_{\mathrm{k} 7}-0.60 \mathrm{k} 4_{\mathrm{k} 6}+1.00_{\mathrm{k} 5}$ & $\mathrm{p}=0.03, \mathrm{R}^{2}=0.14, \mathrm{SEE}=3.31$ \\
\hline Yield of dry matter in monoculture & $\mathrm{p}=0.002, \mathrm{R}^{2}=0.17, \mathrm{SEE}=3.64$ \\
\hline $\mathrm{y}=18.16-0.89_{\mathrm{k} 4}-0.98_{\mathrm{k} 6}-0.95_{\mathrm{k} 8}$ & $\mathrm{l}$ \\
\hline Variance over the trend - of yields of dry matter in crop rotation & $\mathrm{y}=3.26-2.22_{\mathrm{k} 8}$
\end{tabular}

Abbreviations of independent variables: k4...k8, monthly values of Selyaninov's Index, from April to August

maize will increase considerably, as the climate warming will create opportunities for implementing more efficient technological solutions and more productive medium-late and late varieties (Meza and Silva, 2009; Szulc and Kruczek, 2008). However, the extent of this yield increase cannot be estimated solely according to annual data, on which most models are based (Eckersten et al., 2012; Reidsmaa et al., 2009; Southworth et al., 2000), whereas detailed daily data from plant growing seasons are impossible to obtain unless an adequately large set of probable data is generated, as was done in the research reported by Dragańska (Dragańska et al., 2008).

\section{CONCLUSIONS}

1. In the nearly fifty-year-long period of field experiment analysed, there was a significant trend of increasing air temperatures, on average by $0.03^{\circ} \mathrm{C}$ per year. The mean annual temperature rose from $7.1^{\circ} \mathrm{C}$ in the first decade of the period to $8.2^{\circ} \mathrm{C}$ in the last ten years. Atmospheric precipitation oscillated around $600 \mathrm{~mm}$, showing slight fluctuations repeated over periods of ten years.

2. Because of the temperature changes, the Growing Degree Days (GDD) index for maize increased significantly, about 5.32 per year, over the analysed time period.

3. The trend lines plotted for the Selyaninov's Index were insignificant except for April. The frequency of the occurrence of months with sufficient rainfall and ones with a deficit of precipitation was fairly consistent, as indicated by the SPI (standard rainfall index) values.

4. Despite the improved thermal conditions in fifty years, the maize silage yields did not increase year by year, either in a crop rotation or in a monoculture system (in monocultures they were lower by almost $10 \mathrm{th}^{-1}$ on average), but dry matter yields of maize increased significantly.

5. Higher temperatures made early sowing possible, and the plants were able to reach earlier stages of development (trends of change are highly significant). Meanwhile, the duration of the individual plant development stages did not change over time.

6. It has been demonstrated that a later sowing date and delayed plant emergence significantly reduced the yield of maize dry matter. On the other hand, a longer interval between emergence and flowering resulted in an increase in dry matter yield.

7. The largest number of confirmed cases, as a result of correlation analysis, concerned the positive impact of the mean annual temperatures and the growing season mean temperatures on maize productivity. The impact of annual precipitation totals during the vegetation period and in individual months turned out to be ambiguous.

\section{REFERENCES}

Abendrot, I. J., Elmore, R. W., Boyer, M. J., Marlay, S. K. (2011). Corn Growth and Development PMR 1009. Ames, Iowa: Iowa State University Extention. 
Barber, A. S., Mackay, A. D., Kuchenbuch, R. O., Barraclough, P. B. (1988). Effects of soil temperature and water on maize root growth. Plant and Soil, 111(2), 267-269.

Bocchiola, D., Nana, E., Soncini, A. (2012). Impact of climate change scenarios on crop yield and water footprint of maize in the Po valley of Italy. Agric. Water Manage., $116,50-61$.

Butler, E. E., Huybers, P. (2013). Adaptation of US maize to temperature variations. Nature Clim. Change, 3, 68-72.

Dragańska, E., Szwejkowski, Z., Panfil, M. (2008). Wpływ spodziewanych zmian klimatu na fenologię kukurydzy uprawianej na ziarno w Wielkopolsce. Acta Agroph., 12(2), 327-336.

Dudek, S., Zarski, J. (2009). Reakcja kukurydzy na nawadnianie w świetle wyników wieloletniego eksperymentu polowego. Infrastructure and Ecology of Rural Areas, 3, 167-174.

Eckersten, H., Herrmann, A., Kornher, A., Halling, M., Sindhoj, E., Levan, E. (2012). Predicting silage maize yield and quality in Sweden as influenced by climate change and variability. Acta Agric. Scand., Section B Soil \& Plant Sci., 62(2), 151-165.

Elsgaard, L., Børgesen, C. D., Olesen, J. E., Siebert, S., Ewert, S., Peltonen-Sainio, P., Rötter, R.P., Skjelvåg, A. O. (2012). Shifts in comparative advantages for maize, oat and wheat cropping under climate change in Europe. J. Food Additives \& Contamin., 29(10), 1514-1526.

IPCC. (2014). Fifth Assessment Report (AR5). Geneva.

Kovacevic, V., Simic, D., Sootaric, J., Josipovic, M. (2007). Precipitation and temperature regime impacts on maize yields in eastern Croatia. Maydica, 52(3), 301-305.

Kuchar, L. (1989). The exponential polynomial model (EPM) of yield forecasting for spring wheat based on meteorological factors and phenophase. Agric. For. Meteorol., 46(4), 339-348.

Kuchenbuch, R. O., Barber, S. A. (1988). Significance of temperature and precipitation for maize root distribution in the field. Plant and Soil, 106(1), 9-14.

Liu, Z., Yang, X., Hubbard, K. G., Lin, X. (2012). Maize potential yields and yield gaps in the changing climate of northeast China. Global Change Biol., 18(11), 3441-3454.

Lobell, D. B., Hammer, G. L., Mclean, G., Messina, C., Roberts, M. (2013). The critical role of extreme heat for maize production in the United States. Nat. Clim. Change, 3, 497-501.

Lobell, D., B. Burke, M. B. (2008). Why are agricultural impacts of climate change so uncertain? The importance of temperature relative to precipitation. Environ. Res. Lett., 3(2), 2-8.

Meza, F. J., Silva, D. (2009). Dynamic adaptation of maize and wheat production to climate change. Clim. Change, 94(1-2), 143-156.

Reidsmaa, P., Ewert, F., Boogaard, H., van Diepen, K. (2009). Regional crop modelling in Europe: The impact of climatic conditions and farm characteristics on maize yields, 100(1-3), 51-60.

Riha, S. J., Wilks, D. S., Simoens, P. (1996). Impact of temperature and precipitation variability on crop model predictions. Climatic Change, 32(3), 293-311.

Southworth, J., Randolph, J. C., Habeck, M., Doering, O. C., Pfeifer, R. A., Rao, D. G., Johntson, J. J. (2000). Consequences of future climate change and changing climate variability on maize yields in the Midwestern United States. Agric. Ecosys. Environ., 82(1-3), 39-158.

Sulewska, H., Koziara, W. (2005). Influence of weather conditions on yielding and plant development of different maturity maize hybrids. Sci. Pap. Agric. Univ. Poznan, Agriculture, 5, 35-41.

Szulc, P., Kruczek, A. (2008). Wpływ wielkości opadów i temperatury na gromadzenie suchej masy i pobieranie składników mineralnych przez kukurydzę w początkowym okresie rozwoju w zależności od sposobu nawożenia od sposobu nawożenia. Acta Agroph., 11(3), 753-766.

Szwejkowski, Z., Dragańska, E., Cymes, I., Timofte, C., Suchecki, S., Craciun, I. (2017). Rainfall and water conditions in the region of the upper glacial in Europe. Meteorol. Hydrol. Water Manage., 5(1), 15-28.

Tao, F., Zhang, Z. (2010). Adaptation of maize production to climate change in North China Plain: Quantify the relative contributions of adaptation options. Europ. J. Agron., 33(2), 103-116.

Waha, K., Muller, C., Rolinski, S. (2013). Separate and combined effects of temperature and precipitation change on maize yields in sub-Saharan Africa for mid- to late-21st century. Global Planet., 106, 1-12. 


\section{ZMIANY KLIMATU W REGIONIE POLSKI PÓŁNOCNO-WSCHODNIEJ I ICH WPŁYW NA PLONOWA- NIE KUKURYDZY}

\section{ABSTRACT}

\section{Cel pracy}

Wskazanie zmian w plonowaniu kukurydzy na ziarno i na kiszonkę w związku z obserwowanymi zmianami klimatu.

\section{Materiat i metody}

Dane z doświadczeń polowych stacji doświadczalnej Uniwersytetu Warmińsko-Mazurskiego od roku 1972 oraz danych meteorologicznych (temperatury powietrza i opady atmosferyczne).

Obliczenia z wykorzystaniem analizy trendu zmiennych oryginalnych i wyznaczonych indeksów (wskaźniki GDD, SPI, Sielianinowa), modeli liniowych pogoda-plon oraz elementów analizy spektralnej.

\section{Wyniki i wnioski}

Wykazano zmiany warunków termicznych w oparciu o średnie temperatury powietrza i indeks GDD. Nie wykazano istotnych zmian w opadach atmosferycznych, wykazując niewielką okresowość wynoszącą dziesięć lat oraz nie odnotowano zmian w częstotliwości występowania miesięcy z deficytem opadów (analiza SPI).

Odnotowano, że zmiany warunków termicznych a także wprowadzenie nowych odmian kukurydzy w ciągu pięćdziesięciu lat znacznie poprawiły dojrzewanie roślin co dało znaczny wzrost masy ziarna. Nie wpłynęło jednak na plony kukurydzy na kiszonkę ani w płodozmianie, ani w systemie monokultury.

Słowa kluczowe: zmiany klimatu, kukurydza, Polska północno-wschodnia 